\title{
Effect of temperature and time after collection on buck sperm quality
}

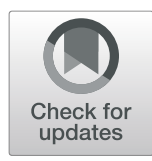

Kirsten Hahn ${ }^{1 *}$ D, Klaus Failing ${ }^{2}$ and Axel Wehrend ${ }^{3}$

\begin{abstract}
Background: Different parameters are assessed as part of the semen analysis but a standard protocol for evaluation of goat semen is still missing. The aim of this study was to analyse two different factors affecting buck sperm quality in the post-collection period prior to adding the extender. Here we examined the effects of two handling temperatures $\left(20^{\circ} \mathrm{C}, 37^{\circ} \mathrm{C}\right)$ and various examination time points (3-30 min) after semen collection.

Results: Examination time point had a significant influence on raw sperm viability $(p<0.05)$, motility $(p<0.05)$ and on semen $\mathrm{pH}(p<0.05)$. The two different handling temperatures had no significant effect on sperm viability $(p>0.05)$, motility ( $p>0.05)$, with the exception of fast moving sperm $(p=0.04)$, or on semen $\mathrm{pH}(p>0.05)$.

Conclusion: Examination time point was identified as factor strongly influencing raw peacock buck semen after collection. Raw goat semen can tolerate room temperatures for at least 10 min without impacting overall semen quality. In order to obtain comparable results, semen samples should always be examined within 10 min after collection.
\end{abstract}

Keywords: Peacock bucks, Temperature, Time point, Computer assisted semen analysis

\section{Background}

Different parameters are assessed as part of the semen analysis including in general volume, color, consistency, impurities as well as semen concentration, motility, vitality and morphology [6]. These are used to determine the suitability of an ejaculate for further use and to establish an insemination dose. Therefore, the handling conditions must be kept as constant as possible during the evaluation. In human medicine, guidelines for semen collection, handling and evaluation of the ejaculates are described [33].

A standard protocol for evaluation of goat semen does not exist. Usually the semen evaluation takes place directly after the collection [26]. In other studies the time interval between collection and evaluation was $2-3$ min [29], after $20 \mathrm{~min}$ [28] or for the entire evaluation within one hour after collection, while concentration, $\mathrm{pH}$ and volume were examined immediately after collection [5]. Busch and Fischer (2007) suggested that the collected semen must be evaluated within $10 \mathrm{~min}$ after

\footnotetext{
* Correspondence: k.hahn@pferd.vetmed.uni-muenchen.de

${ }^{1}$ Equine Hospital, Ludwig-Maximilians-University, Veterinärstraße 13, 80539

Munich, Germany

Full list of author information is available at the end of the article
}

collection, without describing the influence of time on semen quality [6].

The handling temperature during semen evaluation is usually $37^{\circ} \mathrm{C}[5,7,16,25,26,29]$. All materials having contact with the sperm should be preheated to this temperature $[9,27]$.

The sperm of mammals are very sensitive to temperature fluctuations $[18,20]$ with species and individual differences. Equine semen should be kept at $37^{\circ} \mathrm{C}$ prior to dilution [14]. It is known that boar spermatozoa are very susceptible to cold shock, especially when stored lower than $15^{\circ} \mathrm{C}$ [12]. Sperm motility was better for undiluted semen samples stored at $15^{\circ} \mathrm{C}$ and $20^{\circ} \mathrm{C}$ for $48 \mathrm{~h}$ compared to $4{ }^{\circ} \mathrm{C}$ and $39^{\circ} \mathrm{C}$ [34]. In literature different handling temperatures for goat spermatozoa after collection are described varying from $30^{\circ} \mathrm{C}$ to $37^{\circ} \mathrm{C}[6,19,28]$. In general, semen is usually preserved at $18-22^{\circ} \mathrm{C}$ or at $37^{\circ} \mathrm{C}$ until adding an extender [4].

In ruminants $\mathrm{pH}$ of semen is in the slightly acidic with range of 6.4-7.0. Deviations may be due to accessory gland disease and can have an adverse effect on semen viability [31].

At present, however, only a limited number of studies have assessed the factors that can influence the semen 
analysis results of raw goat semen. Although different studies have evaluated the influence of temperature on semen quality in mammal species [3, 17] systematic investigations on caprine semen in this critical postcollection period prior to adding an extender are still missing.

The aim of this study was to investigate two possible factors affecting buck sperm quality after collection prior to adding an extender. Therefore, we evaluated the influence of two different post-collection temperatures $\left(20^{\circ} \mathrm{C}\right.$ and $\left.37^{\circ} \mathrm{C}\right)$ and various examination time points $(3-30$ min) after semen collection on semen quality.

\section{Results}

\section{Macroscopic evaluation}

The volume of the ejaculates was on average $0.48 \mathrm{ml} \pm$ $0.11 \mathrm{ml}$ (minimum: $0.3 \mathrm{ml}$, maximum: $0.8 \mathrm{ml}$ ). The majority $(80 \%)$ of all collected semen samples $(n=20)$ had a yellow color and $20 \%$ were ivory. Consistency was milky in $70 \%$ of the ejaculates and creamy in $30 \%$.

\section{$\mathrm{pH}$ value}

After semen collection, $\mathrm{pH}$ in $65 \%(n=13)$ of the samples were within the reference range (6.4-7.0) for the $\mathrm{pH}$ value of goat semen [31]. About $35 \%(n=7)$ had a slightly increased $\mathrm{pH}$ value of 7.2. All results are shown in Table 1 for both handling temperatures overtime.

Semen $\mathrm{pH}$ was significantly affected by both examination time point $(p<0.0001)$ and temperature $(p=$ 0.002). Further the interaction between duration of storage and handling temperature $(p<0.0001)$ indicated that the $\mathrm{pH}$ decreased faster over time when stored at $37^{\circ} \mathrm{C}$.

Table $1 \mathrm{pH}$ values of fresh ejaculates $(n=20)$ of five peacock bucks at storage temperatures of $20^{\circ}$ and $37^{\circ} \mathrm{C}$ at the specified examination times. Presented by arithmetic mean $(\bar{x})$, standard deviation (SD), minimum and maximum (range)

\begin{tabular}{llll}
\hline Time (min.) & Temperature $\left({ }^{\circ} \mathrm{C}\right)$ & $\bar{x} \pm \mathrm{SD}$ & Range \\
\hline 0 & 20 and 37 & $7.02 \pm 0.19$ & $6.4-7.2$ \\
10 & 20 & $6.97 \pm 0.20$ & $6.4-7.2$ \\
& 37 & $6.83 \pm 0.29$ & $6.4-7.7$ \\
20 & 20 & $6.90 \pm 0.20$ & $6.4-7.2$ \\
& 37 & $6.70 \pm 0.33$ & $<6.4-7.7$ \\
30 & 20 & $6.81 \pm 0.21$ & $6.4-7.2$ \\
& 37 & $6.55 \pm 0.36$ & $<6.4-7.5$ \\
40 & 20 & $6.79 \pm 0.19$ & $6.4-7.0$ \\
& 37 & $6.50 \pm 0.37$ & $<6.4-7.5$ \\
50 & 20 & $6.74 \pm 0.26$ & $<6.4-7.0$ \\
& 37 & $6.42 \pm 0.29$ & $<6.4-7.0$ \\
60 & 20 & $6.69 \pm 0.24$ & $<6.4-7.0$ \\
& 37 & $6.42 \pm 0.29$ & $<6.4-7.0$ \\
\hline
\end{tabular}

\section{Microscopic evaluation}

Semen viability and morphological abnormalities.

The results of semen viability for both handling temperatures and the different examination time points are shown in Fig. 1.

Examination time points influenced proportion of living and dead sperm cells $(p<0.0001)$ whereas the effect of the handling temperature as well as its interaction to the examination time point did not have a significant effect $(p=0.308$ resp. $p=0.458)$. The results are also presented in Table 2. Living and dead sperm were distinguished by their color. Sperm without stain were alive whereas the blue sperm were determined as dead.

The proportion of morphological abnormalities was on average $2.80 \pm 3.45 \%$ at a storage temperature of $20^{\circ} \mathrm{C}$, and $2.45 \pm 2.83 \%$ at $37^{\circ} \mathrm{C}$. The results for all sperm with morphological abnormalities for both storage temperatures are presented in Table 3. This was a single evaluation taken at $3 \mathrm{~min}$.

\section{Sperm motility}

Results of the computer-assisted semen analysis are shown in Table 4 for both temperatures and all examination time points.

The two different handling temperatures had no significant effect on sperm motility $(p>0.05)$ with exception of fast motile sperm $(p=0.04)$. Sperm with a VCL $<$ 90 were defined as slow motile and with a VCL $\geq 90$ are defined as fast motile according to the CASA settings. Examination time point was identified as factor influencing semen motility $(p=0.0012)$ and especially fast motile (progressive) spermatozoa $(p<0.0001)$. Interaction of sample handling temperature and time had a significant influence on the proportion of spermatozoa that are moving in circles $(p=0.0003)$. All data of the two-way ANOVA are presented in Table 2. Essentially, the results of glmm correspond to the two-way ANOVA.

\section{Discussion}

Various factors are known to influencing goat semen quality such as age, breed, season, method of semen collection, extender and centrifugation [1, 2, 11, 15, 29]. In our study we investigated post-collection temperature and time as two possible factors influencing buck semen quality after collection with a focus on raw semen.

Sperm motility is an important parameter which influences fertility of a male animal [13]. Temperature essentially influences semen motility. In one study with dogs, the examined motility parameters at a temperature of 30 degrees were significantly lower compared to 37 degrees [30]. Tuli and Holz (1995) recommend examining sperm motility in isothermal conditions of $36-38^{\circ} \mathrm{C}$. Verstegen et al. (2002) suggested $37^{\circ} \mathrm{C}$ is an ideal temperature for semen evaluation. 


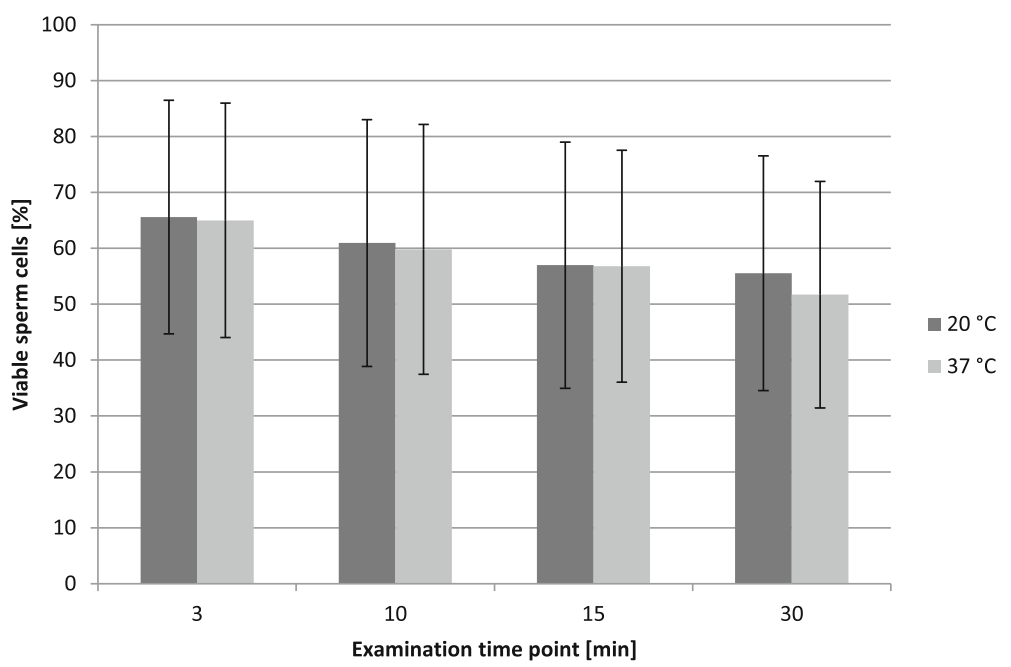

Fig. 1 Proportion of viable sperm cells $(\%)$ in native ejaculates $(n=20)$ of five peacock bucks compared at post-collection temperatures of $20^{\circ}$ and $37^{\circ} \mathrm{C}$ at different examination times $(\bar{x} \pm S D)$

These recommendations do not seem to be applied to raw semen of peacock goat bucks, according to the results of our study. After assessing the measurements of the CASA system, there was a tendency that individual motility of the semen cells was higher at a post-collection temperature of $20^{\circ} \mathrm{C}$ imitating room temperature. A significant influence of temperature was observed on the proportion of fast-motile sperm again with better results when kept at $20^{\circ} \mathrm{C}$. According to our results goat semen can be kept at room temperature after collection and during semen analysis without affecting overall semen quality. However, we compared only two different temperatures in the work. Further studies would be necessary to investigate a larger number of different handling temperatures for raw goat semen.

The interaction effect between post-collection temperature and time of investigation had a significant effect on sperm that exhibited circling in both statistical

Table 2 Results of the two-way ANOVA with repeated measures for the analyzed influencing factors are presented by their $p$-values

\begin{tabular}{llll}
\hline Parameter & Factor & Interaction \\
\cline { 2 - 3 } & Temperature & Time & Temperature $x$ Time \\
\hline Viability & 0.30 & $<0.0001$ & 0.45 \\
$\mathrm{pH}$ & 0.002 & $<0.0001$ & $<0.0001$ \\
Motility & 0.13 & 0.001 & 0.06 \\
Progressive motility & 0.13 & 0.001 & 0.06 \\
Fast motility & 0.04 & $<0.0001$ & 0.05 \\
Slow motility & 0.83 & 0.69 & 0.09 \\
Circle motility & 0.45 & 0.07 & 0.0003 \\
Immotile & 0.13 & 0.001 & 0.06 \\
\hline
\end{tabular}

evaluation methods. With the computer assisted semen analysis, further various movement parameters of sperm can be assessed. To date, studies on the influence on the proportion of spermatozoa moving in circles are missing. According to Pezzanite et al. [23], sperm moving in circles belong to the category of immotile sperm. Waberski and Petrunkina [31] include spermatozoa with circle motility, as long as the circle corresponds at most to the sperm head lengths, to the progressive motile sperm. Possible causes of the circular movement are pathological tail changes, premature hyper-activation, as well as osmotic changes, which can lead to a curling of the flagella.

In addition, the influence of handling temperature on semen viability was investigated. No influence could be

Table 3 Morphological abnormalities of sperm cells from all peacock bucks $(n=5)$ of all collected ejaculates $(n=20)$ presented by arithmetic mean $(\bar{x})$, standard deviation (SD), minimum and maximum (range). This was a single evaluation made at 3 min after collection

\begin{tabular}{llll}
\hline Parameters & Temperature $\left({ }^{\circ} \mathrm{C}\right)$ & $\bar{x} \pm \mathrm{SD}$ & Range \\
\hline Head defects & 20 & $0.17 \pm 0.33$ & $0-1$ \\
& 37 & $0.25 \pm 0.30$ & $0-1$ \\
Tail defects & 20 & $1.45 \pm 2.50$ & $0-11$ \\
& 37 & $1.20 \pm 2.3$ & $0-10.5$ \\
Loose Heads & 20 & $1.07 \pm 1.61$ & $0-5$ \\
& 37 & $0.97 \pm 1.15$ & $0-4.5$ \\
Cytoplasmic droplets & 20 & $0.10 \pm 0.26$ & $0-1$ \\
& 37 & $0.25 \pm 0.11$ & $0-0.5$ \\
Total & 20 & $2.80 \pm 3.45$ & $0-15$ \\
& 37 & $2.45 \pm 2.83$ & $0-13$ \\
\hline
\end{tabular}


Table 4 Measurement results of the motility parameters determined by CASA (AndroVision ${ }^{\oplus}$ system) in the ejaculates ( $n=20$ ) of five peacock bucks at a storage temperature of $20^{\circ}$ and $37^{\circ} \mathrm{C}$. Due to the fact that the statistical distribution of the circle motility was skewed to the right this data is presented by arithmetic mean $(\bar{x})$ and minimum and maximum (range)

\begin{tabular}{llllll}
\hline Parameter & Temperature $\left({ }^{\circ} \mathrm{C}\right)$ & 3 min. $(\bar{x} \pm$ SD) & 10 min. $(\bar{x} \pm$ SD) & 15 min. $(\bar{x} \pm$ SD) & 30 min. $(\bar{x} \pm$ SD) \\
\hline Progressive motility (\%) & 20 & $71.72 \pm 24.05$ & $73.16 \pm 23.11$ & $72.17 \pm 23.61$ & $68.72 \pm 24.69$ \\
& 37 & $73.84 \pm 22.85$ & $67.78 \pm 24.14$ & $71.58 \pm 27.64$ & $59.90 \pm 27.01$ \\
Fast motility (\%) & 20 & $43.31 \pm 26.42$ & $41.43 \pm 25.48$ & $40.61 \pm 25.99$ & $37.37 \pm 25.04$ \\
& 37 & $42.61 \pm 27.82$ & $36.99 \pm 25.81$ & $39.97 \pm 26.16$ & $28.18 \pm 24.06$ \\
Slow motility (\%) & 20 & $27.71 \pm 11.58$ & $30.66 \pm 17.02$ & $30.55 \pm 15.23$ & $30.37 \pm 14.40$ \\
& 37 & $29.60 \pm 16.58$ & $29.91 \pm 11.32$ & $30.82 \pm 17.59$ & $31.10 \pm 14.30$ \\
Circle motility (\%) & 20 & 0.70 (range: 0-2.9) & 1.07 (range: 0-4.4) & 1.02 (range: 0-4.6) & 0.98 (range: 0-3.9) \\
& 37 & 1.23 (range: 0-10.9) & 0.87 (range: 0-3.8) & 0.78 (range: 0-5.5) & 0.62 (range:0-4.3) \\
Immotile (\%) & 20 & $28.28 \pm 24.05$ & $26.84 \pm 23.11$ & $27.83 \pm 23.61$ & $31.28 \pm 24.69$ \\
& 37 & $26.15 \pm 22.85$ & $32.22 \pm 24.14$ & $28.42 \pm 27.65$ & $40.09 \pm 27.01$ \\
\hline
\end{tabular}

demonstrated. According to our results fresh peacock goat semen can be kept at $20^{\circ} \mathrm{C}$ or $37^{\circ} \mathrm{C}$ after collection without influence on semen viability. Murphy et al. [21] also demonstrated no effect of different storage temperatures $\left(5,15,22,32^{\circ} \mathrm{C}\right)$ on liquid bull semen viability.

According to Busch and Fischer (2007) undiluted semen of small ruminants kept at $30^{\circ} \mathrm{C}$ post collection for 20-30 min can still be used for artificial insemination. This statement is comparable to the results in our work. At a post-collection temperature of $20^{\circ} \mathrm{C}$, the obtained ejaculates still achieved the minimum requirements [7] placed on fresh goat semen. The ejaculates kept at $37^{\circ} \mathrm{C}$ were just below the minimum requirements.

For semen quality, a stable $\mathrm{pH}$ is essential. If values below 6.5 are reached, motility and metabolism of the sperm are gradually reduced [32]. In this work, $\mathrm{pH}$ of the semen was stable when the samples were kept at a temperature of $20^{\circ} \mathrm{C}$. At both post-collection temperatures used, however, a steady decrease of the $\mathrm{pH}$ was observed with increasing duration of the tests. Even after $10 \mathrm{~min}$, a lowering of the $\mathrm{pH}$ value could be determined in both experimental batches, but $\mathrm{pH}$ decreased faster at $37^{\circ} \mathrm{C}$. These $\mathrm{pH}$ shifts result from aerobic and anaerobic metabolic products of living and dead sperm. Perhaps there is a relationship between decreasing $\mathrm{pH}$ and decreasing sperm viability. There are individual differences between the bucks with regard to the $\mathrm{pH}$ of the semen. Possibly the individual buck also influences the stability of the $\mathrm{pH}$ value in the raw ejaculate.

Additionally we investigated different examination time points as second influencing factor on goat semen quality. Different data exists regarding the time of semen examination after collection. As a rule, the semen examination is carried out directly after collection $[22,26]$. In other studies, the examination time differed between 2 and $3 \mathrm{~min}$ [29], after $20 \mathrm{~min}$ [28] or within $1 \mathrm{~h}$ after collection $[5,7,10]$.

Examination time significantly influenced semen motility. Especially fast motility was affected and slightly decreased between the examination time points 3 and 10 min. Our results accord to Busch and Fischer (2007) who recommended that the extracted ejaculate must be examined within $10 \mathrm{~min}$ after collection.

The proportion of live sperm decreases with an increasing duration of storage time. Therefore, this parameter should generally be examined as soon as possible after semen collection. In both statistical evaluation methods used here, these observations could be confirmed by the achievement of the given level of significance.

The time had a significant influence on the $\mathrm{pH}$ value of the fresh semen samples. At the later examination times, a decrease in the $\mathrm{pH}$ value could be observed for all goat bucks. The time of examination is therefore important for semen $\mathrm{pH}$ and therefore for the quality of spermatozoa, since the motility and the metabolism can be reduced. The examination and further processing of the sperm should be carried out as soon as possible after collection, since otherwise semen quality can be adversely affected by a reduced $\mathrm{pH}$ value.

Other conditions (aerobic versus anaerobics, light versus dark, presence of urine) play an important role for semen quality. In order to obtain comparable results, it is necessary to use a set of standard conditions. Further studies are needed for an optimal standard protocol for evaluation of goat semen.

\section{Conclusion}

Examination time point was identified as factor influencing fresh peacock goat semen assessment. Semen motility, viability and $\mathrm{pH}$ should be assessed within $10 \mathrm{~min}$ after semen collection. Raw goat semen can tolerate 
room temperatures for at least $10 \mathrm{~min}$ without impacting overall semen quality. In order to obtain comparable results, the same examination time should always be chosen. Andromed ${ }^{\circ}$, a commercial semen extender without animal proteins, was useful for goat semen analysis with the CASA system. Handling temperature influenced fast motile sperm as well as semen $\mathrm{pH}$, with a tendency of slightly better results for both parameters at $20^{\circ} \mathrm{C}$.

\section{Methods}

\section{Animals}

Five clinically and reproductive healthy peacock goats were used for this study (age $<12$ months). All bucks were owned, maintained and managed at the Clinic for Obstetrics, Gynecology and Andrology of Large and Small Animals with Ambulatory Service of the JustusLiebig-University Giessen. The goats were housed in groups under natural light and were given hay, mineral supplement and fresh water ad libitum. The study was performed during January - April 2015. All experimental procedures were approved by the Ethics Committee of Regierungspraesidium Gießen Germany (Approval number A 27/2012). After the study, the animals were still in the possession of the clinic.

\section{Semen collection}

Prior to the beginning of this study, all bucks were trained to use of a special artificial vagina prepared for sheep and goats (Fa. Minitube, Tiefenbach) containing water at $41^{\circ} \mathrm{C}$. We used two different female Alpine goats independent of their stage of cycle for sexual stimulation of the bucks. All semen collections were performed under the same conditions in a separate room. A total of 20 ejaculates (mean $4 \pm 2$ per buck) were obtained. Semen was collected (one ejaculate per buck per collection day) once per week with a break of at least 5 days.

\section{Semen evaluation}

Macroscopic evaluation (volume, color, consistency, smell, impurities) of all ejaculates was performed directly after semen collection. The $\mathrm{pH}$ of each semen sample was measured with $\mathrm{pH}$ indicator-paper calibrated with whole numbers (Fa. Merck group, Darmstadt) every 10 min for $1 \mathrm{~h}$ following collection. Concentration and sperm motion parameters were evaluated using computer assisted semen analysis (CASA, AndroVision ${ }^{\circ}$-System, Fa. Minitube, Tiefenbach) on a plate warmed to $38^{\circ} \mathrm{C}$, negative phase contrast and $\times 10$ objective at 3 , 10, 15 and $30 \mathrm{~min}$ after collection. Due to the high sperm concentration, all samples had to be diluted just before evaluation at each time point for computer analysis (1:29). The extender was previously kept at $20^{\circ} \mathrm{C}$ or $37^{\circ} \mathrm{C}$. The amount of extender depended on the sperm concentration. For this purpose a commercial semen extender without animal proteins was used (Andromed ${ }^{\circ}$ extender, Fa. Minitube, Tiefenbach). Diluted semen samples were filled into Leja ${ }^{\bullet}$ counting chamber slides (Fa. LabIVF, Singapore) and directly a minimum of 2000 sperm cells were analysed. The technical setting parameters of the CASA system are presented in Table 5. Evaluation of semen viability and morphological abnormalities was performed using the bromophenol-nigrosin staining method $[8,24]$. After air-drying, the smear was observed under a phase-contrast microscope (1000x) and for each, 200 sperm were evaluated.

\section{Experimental design}

Influence of handling temperature after collection on semen quality.

After semen collection two semen aliquots (each $100 \mu \mathrm{l})$ were taken from the original sample and aliquots were kept at two different handling temperatures $\left(20^{\circ}\right.$ and $37^{\circ} \mathrm{C}$ ) for further evaluation.

\section{Influence of evaluation time on semen quality}

Microscopic examination was carried out 3, 10, 15 and 30 min after semen collection, except for morphological abnormalities, which were only examined once at $3 \mathrm{~min}$ post semen collection. The $\mathrm{pH}$ of each semen sample was measured every $10 \mathrm{~min}$ for $1 \mathrm{~h}$ following collection.

Table 5 Technical settings of the CASA system AndroVision ${ }^{\circledast}$ version 1.0.0.5; 2012 for motility analysis of buck spermatozoa

\begin{tabular}{|c|c|}
\hline Variables & Settings \\
\hline Depth of sample chamber & $20 \mu \mathrm{m}$ \\
\hline $\begin{array}{l}\text { Temperature during } \\
\text { analysis }\end{array}$ & $38^{\circ} \mathrm{C}$ \\
\hline $\begin{array}{l}\text { Total number of cells } \\
\text { evaluated }\end{array}$ & 2000 spermatozoa \\
\hline Sperm recognition area & $10-100 \mu \mathrm{m}^{2}$ \\
\hline Frame rate & 60 frames $/ \mathrm{s}$ \\
\hline Pixel/um & $1 / 0.54$ \\
\hline Progressive motility & $\begin{array}{l}\text { Every cell that is not "immotile" or "local } \\
\text { motile" }\end{array}$ \\
\hline Immotile & VSL $<12.0$ and $A L H<1.50$ \\
\hline Local motility & $\begin{array}{l}\mathrm{VCL}<60.0 \text { and } \\
\mathrm{VSL}<48.0\end{array}$ \\
\hline Circle motility & $\begin{array}{l}\text { Radius }>9.0 \text { and radius }<90.0 \text { and rotation } \\
>0.70\end{array}$ \\
\hline Slow motility & $V C L<90.0$ \\
\hline Fast motility & others \\
\hline
\end{tabular}

Abbreviations: VCL Velocity curved line $(\mu \mathrm{m} / \mathrm{s}), V S L$ Velocity straight line $(\mu \mathrm{m} / \mathrm{s})$, ALH Amplitude of lateral head displacement $(\mu \mathrm{m})$ 


\section{Statistical analysis}

All data were analysed using the statistical program packages BMDP/Dynamic, Release 8.1 (1993; BMDP Statistical Software, Inc.) and program package R 3.1.2 (2014; Free Software Foundations GNU project, Rpackage Ime4 R-Function Imer) In accordance to the design of the experiment, two-way ANOVA with repeated measures was applied to test the effects of handling temperature and of the time after semen collection as well as their interaction. In the data pseudo-replications were present (some different ejaculates from the identical buck) but the ANOVA could not take the hierarchical structure of the samples into account, in addition. Despite the low sample size per buck, additionally an asymptotic generalized linear mixed model analysis (glmm) with the statistical program package R 3.1.2 was performed to validate the ANOVA results. In case of the morphological sperm abnormalities the statistical distribution of the data was strongly skewed to the right and represents count information. Therefor this data were analyzed with a Poisson regression model using the statistical program package $\mathrm{R}$.

In general, results were considered statistically significant at $p \leq 0.05$.

\section{Abbreviations}

ANOVA: Analysis of variance; CASA: Computer assisted semen anaylsis; Max: Maximum; Min: Minimum; $\mathrm{pH}$ : Decimal logarithm of the reciprocal of the hydrogen ion activity

\section{Acknowledgments}

Not applicable.

\section{Authors' contributions}

$\mathrm{KH}, \mathrm{AW}$ designed the experiment and drafted the manuscript. Samples were collected and analyzed by $\mathrm{KH}$ and animal keepers or students of the university. KF performed the statistical analysis of the results. All authors read and approved the final manuscript.

\section{Funding}

No funding was obtained for this study.

\section{Availability of data and materials}

The datasets used and/or analysed during the current study are available from the corresponding author on reasonable request.

\section{Ethics approval and consent to participate}

All experimental procedures were approved by the Ethics Committee of Regierungspraesidium Gießen Germany (Approval number A 27/2012). All bucks belonged and were maintained and managed at the Clinic for Obstetrics, Gynecology and Andrology of Large and Small Animals with Ambulatory Service of the Justus-Liebig-University Giessen.

\section{Consent for publication}

Not applicable.

\section{Competing interests}

The authors declare that they have no competing interests.

\section{Author details}

${ }^{1}$ Equine Hospital, Ludwig-Maximilians-University, Veterinärstraße 13, 80539 Munich, Germany. ${ }^{2}$ Unit for Biomathematics and Data Processing, Justus-Liebig University, Giessen, Germany. ${ }^{3}$ Clinic for Obstetrics, Gynecology and Andrology of Large and Small Animals with Ambulatory Service, Justus-Liebig-University, Giessen, Germany.

Received: 28 May 2019 Accepted: 9 October 2019

Published online: 22 October 2019

\section{References}

1. Al-Ghalban AM, Tabaa MJ, Kridli RT. Factors affecting semen characteristics and scrotal circumference in Damascus bucks. Small Rumin Res. 2004:53:141-9.

2. Arrebola F, Abecia JA. Effects of season and artificial photoperiod on semen and seminal plasma characteristics in bucks of two goat breeds maintained in a semen collection center. Vet World. 2017;10:521-5.

3. Barbas J, Mascarenhas R. Cryopreservation of domestic animal sperm cells. Cell Tissue Bank. 2009;10:49-62.

4. Batista M, Niño T, Santana M, Alamo D, Castro N, Reyes R, González F, Cabrera F, Gracia A. Influence of the preservation temperature (37, 20, 4, $-196^{\circ} \mathrm{C}$ ) and the mixing of semen over sperm quality of Majorera bucks. Reprod Domest Anim. 2011;46:281-8.

5. Bopape MA, Lehloenya KC, Chokoe TC, Nedambale TL. Comparison of electro ejaculator and artificial vagina on semen collection from south African indigenous goat following assessment by computer aided sperm analysis. Open J AnimSci. 2015;5:210-8.

6. Busch W, Fischer P. Künstliche Besamung bei kleinen Wiederkäuern. In: Busch W, Waberski D, editors. Künstliche Besamung bei Haus- und Nutztieren. Stuttgart: Schattauer; 2007. p. 282-96. German.

7. Choe CY, Kim JG, Cho SR, Son DS, Kim YK, Balasubramanian S, Choe SY, Rho GJ. Influence of seasons, extenders, slow and rapid freezing on seminal characters in Korean native bucks. Reprod Domest Anim. 2006;41:55-60.

8. De Oliveira IRS, Alves HM, Castelo TS, Bezerra FSB, Bezerra ACDS, Silva AR. Correlations between hypoosmotic swelling test and the classical evaluation of goat semen. Ciênc Anim Bras. 2013;14:216-21.

9. Esteso MC, Rodríguez E, Toledano-Díaz A, Castaño C, Pradiee J, LópezSebastián A, Santiago-Moreno J. Descriptive analysis of sperm head morphometry in Iberian ibex (Capra pyrenaica): optimum sampling procedure and staining methods using sperm-class analyzer ${ }^{\oplus}$. Anim Reprod Sci. 2015;155:42-9.

10. Gacitua H, Arav A. Successful pregnancies with directional freezing of large volume buck semen. Theriogenology. 2005;63:931-8.

11. Jiménez-Rabadán P, Ramón M, Garcia-Álvarez O, Maroto-Morales A, del Omo E, Pérez-Guzmán MD, Bisbal A, Fernández-Santos MR, Garde JJ, Soler AJ. Effect of semen collection method (artificial vagina vs. electroejaculation), extender and centrifugation on post-thaw sperm quality of Blanca-Celtibérica buck ejaculates. Anim Reprod Sci. 2012;132:88-95.

12. Johnson LA, Weitze KF, Fiser P, Maxwell WMC. Storage of boar semen. Anim Reprod Sci. 2000;62:143-72.

13. Kathiravan P, Kalatharan J, Karthikeya G, Rengarajan K, Kadirvel G. Objective sperm motion analysis to assess dairy bull fertility using computer-aided system- a review. Reprod Domest Anim. 2011;46:165-72.

14. Katila T. Procedures for handling fresh stallion semen. Theriogenology. 1997; 48:1217-27.

15. Karagiannidis A, Varsakeli S, Karatzas G. Characteristics and seasonal variations in the semen of Alpine, Saanen and Damaskus goat bucks born and raised in Greece. Theriogenology. 2000;53:1285-93.

16. Kozdrowski R, Dubiel A, Bielas W, Dzięciol M. Two protocols of cryopreservation of goat semen with the use of computer-assisted semen analysis system. Acta Vet Brno. 2007;76:601-4.

17. Leboeuf B, Restall B, Salamon S. Production and storage of goat semen for artificial insemination. Anim Reprod Sci. 2000;62:113-41.

18. Lemma A. Effect of cryopreservation on sperm quality and fertility. In: Manafi $M$, editor. Artificial insemination in farm animals. Croatia: In Tech; 2011. p. 191-216.

19. Mara L, Dattena M, Pilichi S, Sanna D, Branca A, Cappai P. Effect of different diluents on goat semen fertility. Anim Reprod Sci. 2007;102:152-7.

20. Medeiros CMO, Forell F, Oliveira ATD, Rodrigues JL. Current status of sperm cryopreservation: why isn't it better? Theriogenology. 2002;57:327-44.

21. Murphy C, Holden SA, Murphy EM, Cromie AR, Lonergan P, Fair S. The impact of storage temperature and sperm number on the fertility of liquidstored bull semen. Reprod FertilDev. 2015;28:1349-59.

22. Pérez B, Mateos E. Effect of photoperiod on semen production and quality in bucks of Verata and Malagueña breeds. Small Rumin Res. 1996;22:23-8. 
23. Pezzanite L, Bridges A, Neary M, Hutchens T. Animal sciences. Breeding soundness examinations of rams and bucks. Purdue University Cooperative Extension Service. 2010;AS-599-W:1-4.

24. Pogorzelski SA. [Untersuchungen zur Kryokonservierung von Schafspermien unter besonderer Berücksichtigung des Einflusses der Verdünner, Verdünnungsprotokolle und Einfriermethoden auf die Spermienqualitätsparameter]. 2006. Doctoral dissertation, Imu. German.

25. Ramukhithi FV, Nedambale TL, Sutherland B, Lehloenya KC.

Cryopreservation of south African indigenous goat semen. Afr J Biotechnol. 2011;10:17898-902.

26. Roof DJ, Bowley S, Price LL, Matsas DJ. Comparison of two commercial extenders for cryopreservation of goat semen without sperm washing. Theriogenology. 2012;77:412-20.

27. Santiago-Moreno J, Coloma MA, Dorado J, Pulido-Pastor A, GómezGuillamon F, Salas-Vega R, Gómez-Brunet A, López-Sebastián A.

Cryopreservation of Spanish ibex (Capra pyrenaica) sperm obtained by electroejaculation outside the rutting season. Theriogenology. 2009;71: 1253-60.

28. Sariözkan S, Bucak MN, Tuncer PB, Taşdemir U, Kinet H, Ulutaş PA. Effects of different extenders and centrifugation/washing on postthaw microscopicoxidative stress parameters and fertilizing ability of angora buck sperm. Theriogenology. 2010;73:316-23.

29. Tuli RK, Holtz W. Effect of season on the freezability of Bor goat semen in the northern temperate zone. Theriogenology. 1995;43:1359-63.

30. Verstegen J, Iguer-Ouada M, Onclin K. Computer assisted semen analyzers in andrology research and veterinary practice. Theriogenology. 2002;57:149-79.

31. Waberski D, Petrunkina AM. Spermatologie. In: Busch W, Waberski D, editors. Künstliche Besamung bei Haus- und Nutztieren. Stuttgart: Schattauer; 2007. p. 99-109. German.

32. Weitze KF, Petrunkina AM. Samenkonservierung, biochemische Grundlagen und Prinzipien der Einfrier- und Auftautechniken. In: Busch W, Waberski D, editors. Künstliche Besamung bei Haus- und Nutztieren. Stuttgart: Schattauer; 2007. p. 119-32. German.

33. World Health Organization. WHO Laboratory Manual for the Examination of Human Semen and Sperm-cervical Mucus Interaction, 4th edn. Cambridge: Cambridge University Press; 1999. p. 1-136.

34. Zou CX, Yang ZM. Evaluation on sperm quality of freshly ejaculated boar semen during in vitro storage under different temperatures.

Theriogenology. 2000;53:1477-88.

\section{Publisher's Note}

Springer Nature remains neutral with regard to jurisdictional claims in published maps and institutional affiliations.

Ready to submit your research? Choose BMC and benefit from:

- fast, convenient online submission

- thorough peer review by experienced researchers in your field

- rapid publication on acceptance

- support for research data, including large and complex data types

- gold Open Access which fosters wider collaboration and increased citations

- maximum visibility for your research: over $100 \mathrm{M}$ website views per year

At $\mathrm{BMC}$, research is always in progress.

Learn more biomedcentral.com/submissions 